\title{
Changes in chemical composition of rapeseed meal during storage, influencing nutritional value of its protein and lipid fractions
}

KEY WORDS: rapeseed oilmeal, feed evaluation, amino acids, protein degradation, fatty acids, oxidation
Received: 22 November 2016

Revised: $\quad 23$ March 2017

Accepted: $\quad 13$ June 2017
${ }^{1}$ Corresponding author:

e-mail: m.bojanowska@am.szczecin.pl

\begin{abstract}
The aim of the study was to analyse the quality changes in rapeseed meal (RSM) in the presence of oxygen and water vapour at elevated temperature. The chemical composition of fresh and after storage $\left(30\right.$ days at $40{ }^{\circ} \mathrm{C}$ and $80 \%$ relative humidity) samples of RSM was determined. In comparison with fresh samples significant differences in the meal after storage in the content of true protein ( 35.7 vs $37.5 \% \mathrm{DM})$, crude fat ( 6.8 vs $7.5 \% \mathrm{DM})$, crude fibre ( $11.5 \mathrm{vs}$ $10.6 \% \mathrm{DM}$ ), methionine (7.7 vs $\left.8.2 \mathrm{~g} \cdot \mathrm{kg}^{-1} \mathrm{DM}\right)$, cysteine ( $\left.8.2 \mathrm{vs} 8.9 \mathrm{~g} \cdot \mathrm{kg}^{-1} \mathrm{DM}\right)$ and arginine, histidine, aspartic acid, glutamic acid, tannic acid and phytic phosphorus were observed. After storage, the content of butyric, caproic, caprylic and palmitoleic acids increased, while concentration of lauric, stearic and oleic acids decreased. Proportion of saturated fatty acids in total fatty acids raised $(19.7$ vs $14.3 \%)$ and that of unsaturated fatty acids declined ( 80.3 vs $85.7 \%$ ). The storage had influence on acid and peroxide values of oil, increasing them to $20.9 \mathrm{mg} \mathrm{KOH} \cdot \mathrm{g}^{-1}$ and $27.08 \mathrm{meq} \cdot \mathrm{kg}^{-1}$, respectively. No significant differences in the content of starch, sugar, some amino acids (including lysine) and polyunsaturated fatty acids in fresh and post-storage meal were noticed. Aflatoxins $\mathrm{B}_{1}$, $B_{2}, G_{1}, G_{2}$ and ochratoxin $A$ were not detected after storage. It can be concluded that storage conditions affect adversely the quality of RSM having the moisture content only slightly above the recommendation ( 12.7 vs $12.5 \%$ ) and simultaneously changing significantly its protein and lipid profiles.
\end{abstract}

\section{Introduction}

Rapeseed meal (RSM) obtained in Europe predominantly from rape seed of double-low varieties $(<2 \%$ erucic acid content in total fatty acids and $<25 \mu \mathrm{M} \cdot \mathrm{g}^{-1}$ glucosinolate content in an oil-free dry matter) is considered as a valuable component of feed mixtures because of its high protein content with well-balanced essential amino acids composition (Mansour et al., 1993), favourable ratio of $n-6 / n-3$ polyunsaturated fatty acids (PUFA) in residual oil (Nguyen et al., 2003), significant amount of minerals and a wide variety of vitamins (Mansour et al., 1993). However, the dietary inclusion of meal, in particular for monogastric animals, is limited due to high content of polysaccharides (crude fibre) (Pustjens et al., 2013) and non-nutritive substances - glucosinolates (Bell, 1995; Tripathi and Mishra, 2007), polyphenolic compounds (Naczk et al., 1998) and phytates (Thompson and Serraino, 1986). The content and digestibility of amino acids is considered to be the main factor influencing effective animal nutrition. Rapeseed protein, preferably balanced, is characterized by lower digestibility than the protein of other 
meals of plant origin, depending on the conditions of toasting (Pertillä et al., 2002; Pastuszewska et al., 2003).

Fine-grained RSM is sold unpacked and may undergo chemical and biochemical changes leading to deterioration. It is known that increased moisture content influences destructively the quality of meals, mainly by stimulating changes in the lipid fraction and the growth of microorganisms (White and Jayas, 1989). During the storage of feed materials, modifications on the protein digestibility and availability of amino acids can also occur, i.a. as a result of their oxidation. An important role in the oxidation of proteins is attributed to products of lipids autoxidation (Sikorski, 2001). The loss of amino acids may also be associated with the Maillard reaction. In addition, lysine and sulphur amino acids are susceptible to reaction with oxidized polyphenols leading to a loss of amino acids and changes in their availability (Finot, 1997).

Over the last ten years, production and exportation of RSM in Europe has still been increasing, causing elongation of supply chain of this feed compound, handled from manufacturers to customers still predominantly in bulk. About $50 \%$ of RSM produced in the last ten years in Poland has been exported to Ireland, Germany, Spain, Denmark, the UK and Sweden - thus mainly by sea transport (FEDIOL, 2016). As demonstrated by the meteorological data, relative humidity of $80 \%$ can be considered as typical for the port of Szczecin (being one of Polish ports handling rapeseed meal) and the temperatures ranging between $30-35{ }^{\circ} \mathrm{C}$ can occur during the summer months (Institute of Meteorology and Water Management, 2016). According to recommendations concerning sea transport of oilseed cakes (TIS Germany, 2011), optimal conditions are: temperature $5-25^{\circ} \mathrm{C}$ and relative humidity not exceeding $70 \%$. In practice, the temperature increase in oil-bearing seed cakes and meals to about $40{ }^{\circ} \mathrm{C}$ during sea transport occurs very often. It is connected with the exothermic processes causing heat accumulation in large volume, as well as it is a consequence of additional external sources of heat from the engine room (TIS Germany, 2011). Vaporization on cold elements, known as 'ship's sweat' is a common phenomenon during passage from warm to cold zones. During a voyage, a continuous heat exchange process between cargo, surrounding air and hold construction appears. Abiotic risks, in particular changeability of seawater temperature, relative air humidity and temperature of ventilating air, are unavoidable.
Studies on RSM storage, especially under conditions of high temperature $\left(30-40{ }^{\circ} \mathrm{C}\right)$ and high relative humidity $(80-85 \%)$, have been carried out very infrequently. These studies were focused on detecting changes in the lipid fraction (LeśmianKordas and Jóźwiak, 1991), determining safe storage time depending on combinations of moisture and temperature $\left(10-50^{\circ} \mathrm{C}\right)$ or assessing the infestation potential to fungi and insects (White and Jayas, 1989), but still little is known about amino acids losses in specific storage conditions.

The objective of this study was to analyse the changes in the RSM in the presence of oxygen and water vapour, at elevated temperature, in particular with regard to amino acids and fatty acids. The changes of chemical composition of RSM under storage for 30 days at $40{ }^{\circ} \mathrm{C}$ and relative humidity of $80 \%$ were determined. Conditions of the research simulated extremely adverse microclimate parameters which appear in practice of sea trade.

\section{Material and methods}

The RSM was obtained from the Wielkopolskie Edible Fat Manufacturing Plant at Szamotuly (ADM Szamotuły, Poland). It was produced under standard processing conditions, which have embraced: grinding and conditioning the seeds, than pressing the oil mechanically, extracting the residual fat with hexane, and finally toasting, drying and cooling the resulting meal. The seeds used for production of tested meal were grown in Poland and according to the manufacturer's declaration were free of GMOs. A sample of the overall research material was stored in a sealed polyethylene bags at $16^{\circ} \mathrm{C}$ until further analysis.

Initial amount of $150 \mathrm{~kg}$ of rapeseed was taken, from which particular samples of $1 \mathrm{~kg}$ each were next separated and placed in an environmental chamber (type KPK 60 U, Mytron, Bio-und Solartechnik GmbH, Rosenhof, Germany) on the glass shelves and then stored in monitored conditions for 30 days. The stability of the chosen temperature $\left(40{ }^{\circ} \mathrm{C}\right)$ and relative humidity $(80 \%)$ was monitored using portable sensor (RH\% T. Logger, AZ.8829, Elmer, Krakow, Poland).

Chemical analyses were carried out in a fresh RSM (samples were prepared and analysed during the first week after production) and in the meal after storage. Moisture content was determined by standard moisture loss-on drying method according to ISO 6496:1999. Crude protein was determined by standard Kjeldahl method (Balthrop et al., 2011), true protein according to Barnstain method, 
involving precipitation of proteins from a sample by using copper sulphate in the solution of sodium hydroxide and determination of nitrogen according to Kjeldahl method. Crude oil and fat were analysed by extraction with a petroleum ether (Balthrop et al., 2011) in an apparatus E-816 Sox (Büchi Labortechnik AG, Flawil, Switzerland). Sugars were determined by the Luff-Schoorl method (Balthrop et al., 2011). The results were expressed as saccharose equivalent. Starch was determined by the polarimetric method, according to Polish Standard PN-R-64785:1994, using a polarimeter POL-S2 (Polygen, Wrocław, Poland). Crude fibre was estimated by digesting the sample in an Ankom Fibre Analyser (Ankom Technology, USA).

Analyses of the other components were carried out according to the following methods: tannins - by the colorimetric method, according to Polish Standard BN-90/9160-42; phytic phosphorus - by the colorimetric method, according to Oberleas'e with modifications (Korol and Matyka, 1988); acid value value of crude oil by titration, according to EN ISO 660:1999+A1:2005; peroxide value of residual crude oil - using methods described in ISO 3960:1998. Fatty acid content was determined by gas chromatography, using 'Buchi Caviezel Method' (Feifel et al., 2000). Amino acids (excluding methionine, cysteine and tryptophan) were determined using the high performance liquid chromatography method (HPLC), with a prior acid hydrolysis (AOAC International, 2000). Sulphur amino acids were determined also by HPLC, after their oxidation to cysteic acid and methionine sulphone and hydrolysing (AOAC International, 2000). Analysis was performed on Amino Acid Analyser AAA 400 Ingos (Laboratory Instruments Division of INGOS Ltd., Prague, Czech Republic) equipped with UV-VIS detector. Tryptophan was determined by HPLC (Degussa, 1998), after prior hydrolysis of samples in a solution of barium hydroxide at $110{ }^{\circ} \mathrm{C}$ for $18 \mathrm{~h}$ (Landry et al., 1992). Analysis was performed on an amino acid analyser System Gold (Beckman Coulter, CA, USA).

Aflatoxins $B_{1}, B_{2}, G_{1}, G_{2}$ and ochratoxin A were determined by HPLC with fluorescence detection using Merck-Hitachi apparatus (Merck, Darmstadt, Germany) according to ISO 14718:1998 and PN-R64833:1998, respectively. The samples were purified in the immunoaffinity columns: Afla Test (Vicam, USA) and OchraPrep (R-Biophan Rhone Ltd., Glasgow, Scotland). The choice of mycotoxins resulted from a review of the literature which shows that the most commonly appearing storage fungi on rapeseed and its meal include those which synthetize aflatoxins and ochratoxin A, i.e. Penicillium and Aspergillus, while Fusarium were not found (White and Jayas, 1989; Magan et al.,1993). Moreover, ochratoxin A is the most common one present during improper storage of grains and oil seeds, including RSM.

Statistical evaluation of the results was carried out using U-Mann Whitney test (Table 1) and analysis of variance (Tables 2-5), employing the Statistica PL version 8.0 (StatSoft Polska, Kraków, Poland). Measurements were made in majority of cases in replicates of six $(n=6)$, except the determinations of basic chemical composition carried out in replicates of three $(n=3)$.

\section{Results}

The water content of tested meal (Table 1) was increasing during first week of the experiment from $10.5 \%$ to $13.3 \%$ (data not presented) and then was decreasing, reaching amount of $12.7 \%$ after 30 days. Organoleptic assessment of the meal revealed decreased fluidity, amended colour, as well as numerous lumps.

Statistically significant $(P \leq 0.05)$ reductions of crude protein $(-1.1 \%)$, true protein $(-4.7 \%)$ and crude fat $(-8.6 \%)$ content were observed, while crude fibre content increased $(+8.3 \%)$, as a result of changes in proportions between the main compounds (Table 1). A decrease in true protein content of about $1.8 \mathrm{~g}$ per $100 \mathrm{~g} \mathrm{DM}$ indicates that more than $4 \%$ of the initial content of polypeptides was cleaved into the free amino acids. Non-protein nitrogen increased by

Table 1. Chemical composition of rapeseed meal at the beginning and the end of 30 -day storage at $40{ }^{\circ} \mathrm{C}$ and $80 \%$ relative humidity

\begin{tabular}{|c|c|c|c|}
\hline \multirow[b]{2}{*}{ Component } & \multicolumn{2}{|c|}{ Rapeseed meal } & \multirow[b]{2}{*}{$P$-value } \\
\hline & initial & $\begin{array}{l}\text { after 30-day } \\
\text { storage }\end{array}$ & \\
\hline Dry matter, $\mathrm{g} \cdot 100 \mathrm{~g}^{-1}$ & $89.5 \pm 0.2$ & $87.3 \pm 0.34$ & - \\
\hline \multicolumn{4}{|l|}{$\mathrm{g} \cdot 100 \mathrm{~g}^{-1} \mathrm{DM}$} \\
\hline crude protein & $38.76 \pm 0.15$ & $38.35 \pm 0.29$ & 0.050 \\
\hline true protein & $37.54 \pm 0.06$ & $35.76 \pm 0.12$ & 0.050 \\
\hline crude fat & $7.47 \pm 0.20$ & $6.83 \pm 0.04$ & 0.050 \\
\hline starch & $5.26 \pm 0.05$ & $5.58 \pm 0.38$ & 0.513 \\
\hline crude fibre & $10.63 \pm 0.22$ & $11.51 \pm 0.48$ & 0.050 \\
\hline sugar & $9.36 \pm 0.36$ & $9.25 \pm 0.43$ & 0.655 \\
\hline Tannic acid, $\mathrm{g} \cdot \mathrm{kg}^{-1} \mathrm{DM}$ & $19.82 \pm 0.42$ & $18.94 \pm 0.18$ & 0.050 \\
\hline $\begin{array}{l}\text { Phytic phosphorus, } \\
\mathrm{mg} \cdot \mathrm{g}^{-1} \mathrm{DM}\end{array}$ & $9.67 \pm 0.20$ & $8.06 \pm 0.09$ & 0.050 \\
\hline \multirow{3}{*}{$\begin{array}{l}\mu \mathrm{g} \cdot \mathrm{kg}^{-1} \\
\quad \text { aflatoxins } \mathrm{B}_{1}, \mathrm{~B}_{2}, \mathrm{G}_{1}, \mathrm{G}_{2} \\
\text { ochratoxin } \mathrm{A}\end{array}$} & & & \\
\hline & $<1^{*}$ & $<1^{*}$ & - \\
\hline & $<0.2^{*}$ & $<0.2^{*}$ & - \\
\hline
\end{tabular}

mean $\pm S D(n=3) ;{ }^{*}$ - mycotoxins in the analysed samples were not detected; values represent the detection limit of used methods 
$0.21 \mathrm{~g}$ per $100 \mathrm{~g}$ DM. The reduction in total nitrogen content from 6.20 to $6.13 \mathrm{~g} \cdot 100 \mathrm{~g}^{-1}$ is associated with the formation of volatile compounds during degradation of nitrogenous substances. Quantitative changes were also statistically significant $(P \leq 0.05)$ for tannins $(-4.4 \%)$ and phytic phosphorus $(-16.6 \%)$. Despite the obvious signs of microbial growth on the meal particles (mold was visible on the samples surface after 20 days of storage), aflatoxins $B_{1}, B_{2}, G_{1}$, $\mathrm{G}_{2}$ and ochratoxin A were not found in any of samples.

There was reported a statistically significant $(P \leq 0.05)$ decrease in the content of most non-essential amino acids (Table 3 ). Essential amino acids turned out to be of higher stability, including lysine and tryptophan, with the exception of methionine, which content decreased by $6 \%$ compared with the initial value (Table 2). Expressing amino acid (AA) content as average g AA per $\mathrm{kg} \mathrm{DM}$, the highest changes between initial and post-storage content occurred in glutamic acid $\left(-2.78 \mathrm{~g} \cdot \mathrm{kg}^{-1} \mathrm{DM}\right)$, aspartic acid $\left(-1.43 \mathrm{~g} \cdot \mathrm{kg}^{-1} \mathrm{DM}\right)$, serine $\left(-1.03 \mathrm{~g} \cdot \mathrm{kg}^{-1}\right.$ $\mathrm{DM})$, cysteine $\left(-0.76 \mathrm{~g} \cdot \mathrm{kg}^{-1} \mathrm{DM}\right)$, histidine $\left(+0.64 \mathrm{~g} \cdot \mathrm{kg}^{-1} \mathrm{DM}\right)$, methionine $\left(-0.5 \mathrm{~g} \cdot \mathrm{kg}^{-1} \mathrm{DM}\right)$ and arginine $\left(+0.41 \mathrm{~g} \cdot \mathrm{kg}^{-1} \mathrm{DM}\right)$. However, the largest relative change in the amino acid content was recorded in relation to cysteine $(-8.5 \%)$, serine $(-6.1 \%)$, methionine $(-6.1 \%)$, histidine $(+5.6 \%)$, aspartic acid $(-4.8 \%)$ and glutamic acid $(-4.3 \%)$.

Table 2. Essential amino acid content in rapeseed meal at the beginning and the end of 30 -day storage at $40^{\circ} \mathrm{C}$ and $80 \%$ relative humidity

\begin{tabular}{lllr}
\hline Amino acid, & \multicolumn{2}{l}{ Rapeseed meal } & \multirow{2}{*}{$P$-value } \\
\cline { 2 - 3 } $\mathrm{g} \cdot \mathrm{kg}^{-1} \mathrm{DM}$ & \multicolumn{2}{l}{ initial } & \multicolumn{2}{l}{ after 30-day storage } & \\
\hline Lysine & $21.69 \pm 0.28$ & $21.35 \pm 0.46$ & 0.151 \\
Threonine & $17.67 \pm 0.45$ & $17.79 \pm 0.24$ & 0.568 \\
Methionine & $8.22 \pm 0.12$ & $7.72 \pm 0.15$ & $<0.001$ \\
Tryptophan & $3.97 \pm 0.17$ & $3.95 \pm 0.05$ & 0.729 \\
Phenylalanine & $15.72 \pm 0.13$ & $15.46 \pm 0.28$ & 0.067 \\
Leucine & $28.26 \pm 0.27$ & $28.14 \pm 0.37$ & 0.532 \\
Isoleucine & $15.39 \pm 0.14$ & $15.2 \pm 0.21$ & 0.104 \\
Arginine & $23.04 \pm 0.27$ & $23.45 \pm 0.21$ & 0.015 \\
Histidine & $11.52 \pm 0.14$ & $12.16 \pm 0.31$ & $<0.001$ \\
Valine & $19.58 \pm 0.21$ & $19.66 \pm 0.25$ & 0.573 \\
Total (mean) & 165.06 & 164.88 & - \\
\hline
\end{tabular}

mean $\pm S D(n=6)$

In the studied meal, the predominant fatty acid was oleic acid, C18:1 (51.8\% of all identified acids). Linoleic acid (C18:2) constitutes about $25 \%$ of the total fatty acids, palmitic acid (C16:0) - 7.5\% and linolenic $(\mathrm{C} 18: 3)-6.5 \%$ (Table 4$)$. In the fresh samples there was also detected the presence of acids having shorter carbon chains i.e. butyric (C4:0),
Table 3. Non-essential amino acid content in rapeseed meal at the beginning and the end of 30 -day storage at $40{ }^{\circ} \mathrm{C}$ and $80 \%$ relative humidity, $\mathrm{g} \mathrm{kg}^{-1} \mathrm{DM}$

\begin{tabular}{llll}
\hline Amino acid, & \multicolumn{2}{l}{ Rapeseed meal } & \multirow{2}{*}{$P$-value } \\
\cline { 2 - 3 } $\mathrm{g} \cdot \mathrm{kg}^{-1} \mathrm{DM}$ & initial & after 30-day storage & \\
\hline Aspartic acid & $29.75 \pm 0.12$ & $28.32 \pm 0.33$ & $<0.001$ \\
Serine & $16.90 \pm 0.26$ & $15.87 \pm 0.11$ & $<0.001$ \\
Glutamic acid & $65.38 \pm 0.29$ & $62.60 \pm 0.56$ & $<0.001$ \\
Proline & $22.03 \pm 0.12$ & $21.77 \pm 0.29$ & 0.065 \\
Glycine & $20.22 \pm 0.12$ & $19.98 \pm 0.36$ & 0.146 \\
Alanine & $17.19 \pm 0.19$ & $16.85 \pm 0.25$ & 0.023 \\
Tyrosine & $11.95 \pm 0.14$ & $12.04 \pm 0.12$ & 0.248 \\
Cysteine & $8.93 \pm 0.20$ & $8.17 \pm 0.25$ & $<0.001$ \\
Total (mean) & 192.35 & 185.60 & - \\
\hline
\end{tabular}

mean $\pm S D(n=6)$

Table 4. Fatty acid proportion in lipids of rapeseed meal before and after 30 -day storage at $40^{\circ} \mathrm{C}$ and $80 \%$ relative humidity

\begin{tabular}{|c|c|c|c|}
\hline \multirow{2}{*}{ Fatty acid, \% } & \multicolumn{2}{|c|}{ Rapeseed meal } & \multirow{2}{*}{$P$-value } \\
\hline & initial & after 30-day storage & \\
\hline $\mathrm{C} 4: 0$ & $0.58 \pm 0.16$ & $2.09 \pm 0.54$ & $<0.001$ \\
\hline C6:0 & $1.45 \pm 0.26$ & $3.35 \pm 0.99$ & 0.005 \\
\hline C8:0 & $0.87 \pm 0.33$ & $2.08 \pm 1.23$ & 0.058 \\
\hline $\mathrm{C} 10: 0$ & $0.29 \pm 0.09$ & $0.17 \pm 0.13$ & 0.219 \\
\hline $\mathrm{C} 12: 0$ & $0.52 \pm 0.15$ & $0.22 \pm 0.14$ & $<0.001$ \\
\hline C14:0 & $1.35 \pm 0.29$ & $1.97 \pm 0.83$ & 0.068 \\
\hline C16:0 & $7.46 \pm 0.43$ & $7.44 \pm 0.44$ & 0.355 \\
\hline C16:1 & $1.18 \pm 0.15$ & $1.68 \pm 0.12$ & $<0.001$ \\
\hline C18:0 & $1.66 \pm 0.35$ & $1.20 \pm 0.12$ & 0.019 \\
\hline C18:1 & $51.81 \pm 0.80$ & $46.90 \pm 2.15$ & 0.002 \\
\hline C18:2 & $25.09 \pm 0.65$ & $24.44 \pm 0.84$ & 0.249 \\
\hline C18:3 & $6.52 \pm 0.61$ & $6.66 \pm 0.78$ & 0.745 \\
\hline $\mathrm{C} 20: 0$ & $0.16 \pm 0.39$ & $1.13 \pm 0.98$ & 0.095 \\
\hline $\mathrm{C} 20: 1$ & $1.14 \pm 1.30$ & $0.67 \pm 0.85$ & 0.458 \\
\hline Total SFA & $14.26 \pm 1.19$ & $19.65 \pm 2.95$ & 0.006 \\
\hline Total UFA & $85.74 \pm 1.19$ & $80.35 \pm 2.95$ & 0.006 \\
\hline MUFA & $54.13 \pm 1.08$ & $49.25 \pm 2.50$ & 0.004 \\
\hline PUFA & $31.61 \pm 0.74$ & $31.10 \pm 1.24$ & 0.518 \\
\hline
\end{tabular}

mean values $\pm S D(n=6)$; SFA - saturated fatty acids; UFA - unsaturated fatty acids; MUFA - monounsaturated fatty acids; PUFA - polyunsaturated fatty acids

caproic (C6:0) and caprylic (C8:0), with the proportions in total fatty acids content of $0.6 \%, 1.4 \%$ and $0.8 \%$, respectively. Among fatty acids of longer carbon chain, a small amount of gadoleic acid (C20:1) was present, constituting about $1.1 \%$ of the total fatty acids.

There was found a loss of meal quality associated with changes due to hydrolytic and oxidative processes in the lipid fraction. Statistically significant differences $(P<0.001)$ were observed with regard to peroxide value and acid value of residual oil (Table 5). After storage, the peroxide value 
Table 5. Acid value, peroxide value and fatty acid content in rapeseed meal before and after 30 -day storage at $40{ }^{\circ} \mathrm{C}$ and $80 \%$ relative humidity

\begin{tabular}{|c|c|c|c|}
\hline \multirow[b]{2}{*}{ Indices } & \multicolumn{2}{|c|}{ Rapeseed meal } & \multirow[b]{2}{*}{$P$-value } \\
\hline & initial & $\begin{array}{l}\text { after 30-day } \\
\text { storage }\end{array}$ & \\
\hline $\begin{array}{l}\text { Peroxide value, meq } \cdot \mathrm{kg}^{-1} \\
\text { of residual fat }\end{array}$ & $14.94 \pm 0.37$ & $27.08 \pm 2.83$ & $<0.001$ \\
\hline $\begin{array}{l}\text { Acid value, } \mathrm{mg} \mathrm{KOH} \cdot \mathrm{g}^{-1} \\
\text { of residual fat }\end{array}$ & $17.30 \pm 0.47$ & $20.92 \pm 0.30$ & $<0.001$ \\
\hline \multicolumn{4}{|l|}{ Fatty acids, $g \cdot 100 \mathrm{~g}^{-1} \mathrm{DM}$} \\
\hline $\mathrm{C} 4: 0$ & $0.04 \pm 0.01$ & $0.16 \pm 0.03$ & $<0.001$ \\
\hline $\mathrm{C} 6: 0$ & $0.10 \pm 0.02$ & $0.25 \pm 0.09$ & 0.004 \\
\hline C8:0 & $0.06 \pm 0.02$ & $0.16 \pm 0.10$ & 0.631 \\
\hline C10:0 & $0.02 \pm 0.01$ & $0.01 \pm 0.01$ & 0.269 \\
\hline $\mathrm{C} 12: 0$ & $0.03 \pm 0.01$ & $0.01 \pm 0.01$ & 0.003 \\
\hline C14:0 & $0.10 \pm 0.02$ & $0.15 \pm 0.05$ & 0.073 \\
\hline C16:0 & $0.54 \pm 0.02$ & $0.55 \pm 0.05$ & 0.327 \\
\hline C16:1 & $0.09 \pm 0.01$ & $0.12 \pm 0.01$ & $<0.001$ \\
\hline C18:0 & $0.12 \pm 0.02$ & $0.09 \pm 0.01$ & 0.024 \\
\hline C18:1 & $3.72 \pm 0.08$ & $3.49 \pm 0.10$ & 0.002 \\
\hline C18:2 & $1.80 \pm 0.06$ & $1.82 \pm 0.11$ & 0.681 \\
\hline C18:3 & $0.47 \pm 0.05$ & $0.50 \pm 0.07$ & 0.515 \\
\hline $\mathrm{C} 20: 0$ & $0.01 \pm 0.01$ & $0.08 \pm 0.08$ & 0.080 \\
\hline $\mathrm{C} 20: 1$ & $0.08 \pm 0.04$ & $0.05 \pm 0.04$ & 0.427 \\
\hline
\end{tabular}

mean $\pm S D(n=6)$

exceeded the thresholds set in EU rules for lipids being components of feedstuffs, at a level of $20 \mathrm{meq}$ per $\mathrm{kg}$ of fat.

Statistically significant differences were noted between fresh and after-storage samples in relation to the content of following fatty acids: butyric (C4:0), caproic (C6:0), lauric (C12:0), palmitoleic (C16:1), stearic (C18:0) and oleic (C18:1) (Table 5). The largest absolute decline was recorded in case of oleic acid, C18:1 ( -0.23 g per $100 \mathrm{~g} \mathrm{DM})$, while the greatest absolute increase occurred in the content of caproic acid, C6:0 (0.15 g per $100 \mathrm{~g} \mathrm{DM})$. There was no correlation between the degree of unsaturation or the length of the carbon chain and the direction of change (increase/decline of content). A decrease of content of the following acids: lauric (C12:0), stearic (C18:0), oleic (C18:1) and an increase of the content of next ones: butyric (C4:0), caproic (C6:0), palmitoleic (C16:1) were observed. Striking is the stability of PUFA, of which content in the meal did not change significantly.

All the above presented changes resulted in the increase of the proportion of saturated fatty acids (SFA) from $14.3 \%$ to $19.7 \%$ in total fatty acids and in the decrease of the proportion of unsaturated fatty acids (UFA) from $85.7 \%$ to $80.3 \%$ (Table 4 ). After 30 days of storage, fatty acids having a chain length $\mathrm{C} \leq 8$ together accounted for $7.5 \%$ of the total fatty acids, while initial share was only $2.8 \%$. The ratio of UFA/SFA decreased from 6.0 to 4.0 , while the ratio of PUFA/SFA from 2.2 to 1.6.

\section{Discussion}

The initial composition of the investigated meal was within the range presented in the literature (Jensen et al., 1995; Wiąz et al., 2005; Almeida et al., 2014). The biological value of protein for animal critically depends on a few amino acids: lysine, threonine, tryptophan and sulphur amino acids. When comparing the amino acid content in the tested meal with the literature data (Perttilä et al., 2002; Almeida et al., 2014), the content of lysine, threonine and tryptophan in the investigated fresh meal was in accordance with the reference values and remained at similar, acceptable level at the end of the experiment. Referring to sulphur amino acids, their relatively high content in fresh investigated meal was found, however considerable quantitative losses of methionine and cysteine after experiment were observed.

Non-polar amino acids, i.e. glycine, alanine, valine, leucine, isoleucine proved to be more stable than the polar ones, i.e. aspartic acid, glutamic acid, arginine, histidine, suggesting a high significance of hydrolysing processes in protein and less importance of oxidation in selected experimental conditions. Profile of changes of amino acid content gives background to the recognition of microbial activity in the processes of degradation of proteins in tested meal. This interpretation is supported by the significant reduction in the content of aspartic acid $(-4.8 \%)$ and glutamic acid $(-4.3 \%)$ which are considered as an important source of amino groups used by organisms for the synthesis of amino acids and proteins and the simultaneous increase of the content of histidine $(+5.6 \%)$ and arginine $(+1.78 \%)$. Moreover, aspartic acid, glutamic acid, serine and alanine, of which concentration was reduced are not listed among amino acids most easily prone to oxidation, but considered as absorbable and susceptible to microbiological degradation (Sikorski, 2001).

However, assuming that the cause of statistically significant increase in the content of histidine and arginine is their synthesis by proliferating microorganisms, it can not be excluded that a part of amount of other amino acids present in the meal is of microbial origin. Thus, the stability of some amino acids (e.g., lysine) may be only a consequence of the quantitative balance between their decrease in the meal protein and increase resulting from the microflora protein synthesis. 
Results concerning protein differ from expectations as they are not in agreement with literature model changes, according to which, besides sulphur amino acids, also lysine, tryptophan, histidine and arginine become rapidly degraded (Finot, 1997; Sikorski, 2001). In the group these amino acids, only for methionine and cysteine statistically significant concentration decrease was recorded. The highest lability of sulphur amino acids relative to lysine, in rapeseed meal (RSM) may be however, in opinion of this paper's author, associated with lower complexation of methionine and cysteine with fibre (compared with lysine), determined as neutral detergent fibre (NDF). The findings of other studies indicate that a part of RSM protein is strongly complexed with fibre, particularly in case of meal overheating during toasting (Buraczewska et al., 1998). Uneven distribution of amino acids between hulls and embryo of rape seed, reported by Jensen et al. (1995) is probably the cause of variations in their binding with fibre being present in highest proportion in hulls. From $20 \%$ to $40 \%$ lysine in the meal from rape seed may be permanently associated with the fibre, while the complexed cysteine accounted only for about $13 \%$ of total content (Buraczewska et al., 1998). It can be assumed that amino acids being not fibre-bound are more easily absorbable for the microflora of stored meal.

Amino acids losses (including valuable sulphur AA) reduce the quality of protein intended for monogastric animals. The consequences of these changes may be much wider than the scope of experiments presented in this paper. Finot (1997) considers that the loss of amino acids during storage, is largely the result of the Maillard reaction leading to formation of complexes resistant to enzymatic digestion. Resistance to proteolytic enzymes exhibit also crosslinking of proteins with polypeptide chains or within the same protein chain. Changes in availability of some amino acids may be also caused by reaction with oxidized polyphenols (Finot, 1997). The decrease in the content of tannin in the researched meal was found statistically significant. The main direction of tannin's changes is the polymerization of quinones being the products of polyphenols oxidation, which results in brown macromolecular compounds. The presence of amines which react with the quinones can accelerate the formation of brown melanin. The dark-brown colour of meal reported after storage suggests the oxidative character of changes of tannins.

Considering the almost two-fold increase in peroxide value and increase in acid value of residual oil of the tested meal, in the course of the lipid fraction changes, both oxidation and hydrolysis processes took place. The increase in short and medium chain fatty acids content, mainly butyric (C4:0), caproic (C6:0) and caprylic (C8:0) acids can result from oxidation of SFA (statistically significant decrease in the content of $\mathrm{C} 12: 0$ and $\mathrm{C} 18: 0$ ), which may lead to the formation of shorter chain fatty acids or can be associated with hydrolytic changes. Analysing the relative change in the SFA content in dry weight of the samples, it was found that the largest relative decrease was recorded for the lauric acid C12:0 (66\% of initial amount of C12:0 was lost vs $25 \%$ in the case of C18:0). According Dierick and Decuypere (2002), during hydrolysis of triacyloglycerols (TAGs), lipolysis of shorter chains, especially of SFA, occurs easier. Therefore, it seems likely that hydrolytic cleavage of lauric acid (C12:0) and stearic acid (C18:0) from TAGs by chemical reaction or with the participation of enzymes of microbial origin and further transformations, including oxidation, resulted in a decrease of their concentration.

However, the content of PUFA C18:2 and C18:3, being essential fatty acids, remained almost constant during 30 days of storage (changes were statistically insignificant). Under conditions of high water activity (0.8), oleic acid was less stable towards oxidation and hydrolytic cleavage than PUFA. Analysis of possible reasons for this result did not resolve this issue unambiguously. The external position of oleic acid (C18:1) in TAGs of rape seed lipid seems to be the more likely cause. It has been found that linoleic acid (C18:2) and linolenic acid (C18:3) in rape seed of double low varieties 00 occupy a preferential $n-2$ position of glycerol in TAGs, in proportions depending on the content (Richards et al., 2008). At the 1(or 3) - positions the oleic acid and SFA are linked. However, there are conflicting results of studies on the influence of the position of UFA esterified with glycerol on the oxidation rate (Wada and Koizumi, 1983; Neff and El-Agaimy, 1996). Another possible cause may also be selective towards PUFA inhibiting acting of water, similar to that occurring in emulsions of the type 'oil in water' (Miyashita, 2008).

Changes in the profile of UFA did not confirm the correlation between susceptibility to degradation (in assumption caused primary by oxidation) and degree of unsaturation. Similar results were obtained in earlier studies related to storage of RSM and rapeseed cake, however they were often divergent, depending on the conditions. In experiments on RSM, in two combinations of conditions 
$\left(20{ }^{\circ} \mathrm{C} / 85 \% ; 40{ }^{\circ} \mathrm{C} / 60 \%\right)$ after forty days of treatment, a decline in the content of linolenic acid (C18:3), oleic acid (C18:1) and increase of linoleic acid (C18:2) were observed (Leśmian-Kordas and Jóźwiak, 1991). On the other hand, at $40{ }^{\circ} \mathrm{C}$ and $\mathrm{RH}$ of $85 \%$, the concentration of linoleic and linolenic acids decreased, while of oleic acid increased. In turn, in the study concerning rapeseed cake stability under storage in various ambient air parameters for eight months, the decrease in content of monounsaturated fatty acids (MUFA) and the increase of PUFA were found (Osek, 2000).

The reduction in the content of oleic acid in RSM in certain conditions with simultaneous constant concentration of PUFA indicates that both the interaction between compounds of feed (e.g., antioxidants and lipids) and the presence of moisture during storage may alter lability of fatty acids, determined in experimental model systems.

\section{Conclusions}

Inactivation of rapeseed enzymes during processing of the meal as well as the presence of natural antioxidants such as tocopherols and phenolic compounds, are not sufficient to ensure stable chemical composition of rapeseed meal (RSM) being subjected to temperature, oxygen and water vapour changes in ambient air. Changes such as a loss of sulphur amino acids, increase of peroxide and acid values, unfavourable decline in ratio unsaturated to saturated fatty acids and rise of crude fibre concentration may take place in RSM having moisture content of $12.7 \%$ - i.e. only slightly above the trade recommendation level (below $12.5 \%$ according to FEDIOL, 2016). So, the additional stabilization of meal by preservatives may be considered by oil industry. The changes in protein and lipid fractions of RSM at a certain storage conditions affect adversely its quality, however in order to assess their influence on nutritive value of RSM, adequate in vivo and in vitro studies are needed.

\section{References}

Almeida F.N., Htoo J.K., Thomson J., Stein H.H., 2014. Effects of heat treatment on the apparent and standardized ileal digestibility of amino acid in canola meal fed to growing pigs. Anim. Feed Sci.Technol. 187, 44-52, https://doi.org/10.1016/j.anifeedsci.2013.09.009

AOAC International, 2000. Official Methods of Analysis of the Association of Official Analytical Chemists. $17^{\text {th }}$ Edition. Gaithersburg, MD (USA)
Balthrop J., Brand B., Cowie R.A., Danier J., De Boever J., de Jonge L., Jackson F., Makkar H.P.S., Piotrowski Ch., 2011. Quality Assurance for Animal Feed Analysis Laboratories. FAO Animal Production and Health Manual No. 14. FAO, Rome (Italy)

Bell J.M., 1995. Meal and by-product utilization in animal nutrition. In: D.S. Kimber, D.I. McGregor (Editors). Brassica Oilseeds: Production and Utilization. CAB International, Wallingford (UK), pp. 301-337

BN-90/9160-42. Animal feeding stuffs - Determination of tannins in the seed of coarse-grained leguminous plants (in Polish)

Buraczewska L., Gdala J., Wasilewko J., Buraczewski S., 1998. Ileal digestibility in pigs of protein and amino acids of heat treated rapeseed feeds as affected by protein associated with the NDF fraction (in Polish). Rośl. Oleiste - Oilseed Crops XIX, 175-186

Degussa, 1998. Quantitative determination of tryptophan in compound feeds and feed ingredients by HPLC. Feedback, 1-11

Dierick N.A., Decuypere J.A., 2002. Endogenous lipolysis in feedstuffs and compound feeds for pigs: effect of storage time and conditions and lipase and/or emulsifier addition. Anim. Feed Sci. Technol. 102, 53-70, https://doi.org/10.1016/S03778401(02)00224-9

EN ISO 660:1999+A1:2005. Animal and vegetable fats and oils - Determination of acid value and acidity

FEDIOL, 2016 <www.fediol.be>

Feifel S., Lüscher H., Pendl R., 2000. State-of-the-art Food Analyses fast and reliable quantification of fatty acids, reference methods. Büchi Information Bulletin 1

Finot P.A., 1997. Effects of processing and storage on the nutritional value of food proteins. In: S. Damodaran, A. Paraf (Editors). Food Proteins and Their Applications. Marcel Dekker Inc., New York (USA)

Institute of Meteorology and Water Management - National Research Institute (Poland), 2016 <http://www.imgw.pl>

ISO 6496:1999. Animal feeding stuffs - Determination of moisture and other volatile matter content

ISO 3960:1998. Animal and vegetable oils and fats - Determination of peroxide value

ISO 14718:1998. Animal feeding stuffs - Determination of aflatoxin B1 content of mixed feeding stuffs - Method using high-performance liquid chromatography

Jensen S.K., Liu Y.-G., Eggum B.O., 1995. The influence of seed size and hull content on the composition and digestibility of rapeseed in rats. Anim. Feed Sci. Technol. 54, 9-19, https://doi. org/10.1016/0377-8401(94)00762-X

Korol W., Matyka S., 1988. Comparison of methods for the determination of phytic acid in grain and legumes seeds (in Polish). Bull. Feed Ind. 27, 45

Landry J., Delhaye S., Jones D.G., 1992. Determination of tryptophan in feedstuffs: comparison of two methods of hydrolysis prior to HPLC analysis. J. Sci. Food Agric. 58, 439-441, https://doi. org/10.1002/jsfa.2740580321

Leśmian-Kordas R., Jóźwiak Z., 1991. The research on the optimization of conditions of storage and carriage of rapeseed meal (in Polish). Sci. J. Marit. Univ. Szczecin 42, 37-46

Magan N., Jenkins N.E., Howarth J., 1993. Lipolytic activity and degradation of rapeseed oil and rapeseed by spoilage fungi. Int. J. Food Microbiol. 19, 217-227, https://doi.org/10.1016/01681605(93)90079-V

Mansour E.H., Dworschák E., Lugasi A., Gaál Ö., Barna É., Gergely A., 1993. Effect of processing on the antinutritive factors and nutritive value of rapeseed products. Food Chem. 47, 247-252, https://doi.org/10.1016/0308-8146(93)90156-A 
Miyashita K., 2008. Polyunsaturated lipid oxidation in aqueous system. In: C.C. Akoh, D.B. Min (Editors). Food Lipids. Chemistry, Nutrition and Biochemistry. $3^{\text {rd }}$ Edition. CRC Press, Bota Raton, FL (USA), https://doi.org/10.1201/9781420046649.ch13

Naczk M., Amarowicz R., Sullivan A., Shahidi F., 1998. Current research developments on polyphenolics of rapeseed/canola: a review. Food Chem. 62, 489-502, https://doi.org/10.1016/ S0308-8146(97)00198-2

Neff W.E., El-Agaimy M., 1996. Effect of linoleic acid position in triacylglycerols on their oxidative stability. Lebensm.-Wiss. Technol. - Food Sci Technol. 29, 772-775, https://doi.org/10.1006/ fstl.1996.0121

Nguyen C.V., Smulikowska S., Mieczkowska A., 2003. Effect of linseed and rapeseed or linseed and rapeseed oil on performance, slaughter yield and fatty acid deposition in edible parts of carcass in broiler chickens. J. Anim. Feed Sci. 12, 271-288, https://doi.org/10.22358/jafs/67703/2003

Osek M., 2000. Influence of storage time and conditions on changes in lipid fractions of some rapeseeds products (in Polish). Rośl. Oleiste - Oilseed Crops XXI, 145-156

Pastuszewska B., Jabłecki G., Buraczewska L., Dakowski P., Taciak M., Matyjek R., Ochtabińska A., 2003. The protein value of differently processed rapeseed solvent meal and cake assessed by in vitro methods and in tests with rats. Anim. Feed Sci. Technol. 106, 175-188, https://doi.org/10.1016/S03778401(03)00005-1

Perttilä S., Valaja J., Partanen K., Jalava T., Venäläinen E., 2002. Apparent ileal digestibility of amino acids in protein feedstuffs and diet formulation based on total vs digestible lysine for poultry. Anim. Feed Sci. Technol. 98, 203-218, https://doi. org/10.1016/S0377-8401(02)00031-7

PN-R-64785:1994. Animal feeding stuffs - Determination of starch content by polarimetric method (in Polish)

PN-R-64833:1998. Animal feeding stuffs - Methods of ochratoxin A determination (in Polish)
Pustjens A.M., Schols H.A., Kabel M.A., Gruppen H., 2013. Characterisation of cell wall polysaccharides from rapeseed (Brassica napus) meal. Carbohyd. Polym. 98, 1650-1656, https://doi. org/10.1016/j.carbpol.2013.07.059

Richards A., Wijesundera C., Salisbury P., 2008. Genotype and growing environment effects on the tocopherols and fatty acids of Brassica napus and B. juncea. J. Am. Oil Chem. Soc. 85, 159-168, https://doi.org/10.1007/s11746-007-1181-y

Sikorski Z.E., 2001. Chemical reactions in proteins in food systems. In: Z.E. Sikorski (Editor). Chemical and Functional Properties of Food Proteins. CRC Press, Bota Raton, FL (USA)

Thompson L.U., Serraino M.R., 1986. Effect of phytic acid reduction on rapeseed protein digestibility and amino acids absorption. J. Agric. Food Chem. 34, 468-469, https://doi.org/10.1021/ jf00069a023

TIS (Transport Information Service) Germany, 2011. Cargo loss prevention information from German Marine Insurers <www.tisgdv.de>

Tripathi M.K., Mishra A.S., 2007. Glucosinolates in animal nutrition: A review. Anim. Feed Sci. Tech. 132, 1-27, https://doi. org/10.1016/j.anifeedsci.2006.03.003

Wada S., Koizumi C., 1983. Influence of the position of unsaturated fatty acid esterified glycerol on the oxidation rate of triglyceride. J. Am. Oil Chem. Soc. 60, 1105-1109, https://doi. org/10.1007/BF02671335

White N.D.G., Jayas D.S., 1989. Safe storage conditions and infestation potential of canola meal by fungi and insects. J. Stored Prod. Res. 25, 105-114, https://doi.org/10.1016/0022474X(89)90020-9

Wiąz M., Mroczyk W., Józefiak D., Rutkowski A., 2005. Composition of rapeseed cakes and meals manufactured under different technological conditions. J. Anim. Feed Sci. 14, Suppl. 1, 507-510, https://doi.org/10.22358/jafs/70718/2005 